\title{
Pengembangan Perangkat Pembelajaran Collaborative Learning Berbasis Kearifan Lokal untuk Meningkatkan Karakter Nasionalisme dan Kreatif
}

\author{
Arifah Nur \\ SD Payak. Desa Srimulyo, Kecamatan Piyungan, Bantul, 55792, Indonesia \\ Korespondensi Penulis. Email: ariefahnur12@gmail.com \\ Received: 29 March 2016; Revised:2 June 2016; Accepted: 14 June 2016
}

\begin{abstract}
Abstrak
Penelitian ini bertujuan untuk (1) menghasilkan perangkat pembelajaran collaborative learning berbasis kearifan lokal yang layak untuk meningkatkan karakter nasionalisme dan kreatif siswa, dan (2) mengetahui keefektifan perangkat pembelajaran collaborative learning berbasis kearifan lokal untuk meningkatkan karakter nasionalisme dan kreatif siswa. Penelitian ini merupakan penelitian dan pengembangan yang mengacu pendapat Borg \& Gall, tetapi desain pengembangan perangkat pembelajaran ini hanya meliputi 9 langkah, yaitu (1) penelitian pendahuluan dan pengumpulan informasi, (2) perencanaan, (3) pengembangan draf produk, (4) uji coba terbatas, (5) revisi hasil uji coba terbatas, (6) uji coba lapangan, (7) penyempurnaan produk hasil uji coba lapangan, (8) uji coba lapangan operasional, dan (9) penyempurnaan produk akhir. Subjek penelitian adalah siswa kelas IV SD Piyungan Bantul. Hasil penelitian menunjukan bahwa perangkat pembelajaran ini layak digunakan menurut ahli materi dan ahli pembelajaran dengan kategori sangat valid. Berdasarkan hasil penelitian diketahui bahwa terdapat perbedaan yang signifikan pada karakter nasionalisme dan kreatif antara siswa yang mengikuti pembelajaran dengan perangkat pembelajaran collaborative learning berbasis kearifan lokal dan yang tidak menggunakan perangkat pembelajaran hasil pengembangan.
\end{abstract}

Kata Kunci: perangkat pembelajaran collaborative learning, nasionalisme, kreatif.

\section{Developing Collaborative Learning Kits Based on Local Wisdom to Improve Nationalism and Creative Character}

\begin{abstract}
This study aims to (1) produce a collaborative learning kit based on local wisdom that is feasible to improve nationalism and creative character and (2) find out the effectiveness of the collaborative learning kit based on local wisdom to improve nationalism and creative character. This study is a research and development refering to the opinion of Borg \& Gall, but the design of learning kits consists of only nine steps, including (1) research and information collection, (2) planning, (3) developing preliminary form of draft product, (4) preliminary field testing, (5) main product revision, (6) main field testing, (7) operational product testing, (8) operational field testing, and (9) final product revision. Subjects were fourth grade students Piyungan Bantul. The results show that the learning kit is effective to improve nationalism and creative character of students according to the material expert and learning expert with very valid assessment category. Based on the result it shows that there are significant differences in nationalism and creative character between students who take the study with collaborative learning kits based on local wisdom and those who do not use learning kits.
\end{abstract}

Keywords: collaborative learning kits, nationalism, creative

How to Cite: Nur, A. (2017). Pengembangan perangkat pembelajaran collaborative learning berbasis kearifan lokal untuk meningkatkan karakter nasionalisme dan kreatif. Jurnal Prima Edukasia, 5(1), 1-10. doi:http://dx.doi.org/10.21831/jpe.v5i1.8288

Permalink/DOI: http://dx.doi.org/10.21831/jpe.v5i1.8288 


\section{Pendahuluan}

Pendidikan merupakan salah satu sarana untuk membangun kecerdasan sekaligus kepribadian manusia. Seperti yang tertuang dalam Pasal 1 angka 1 UU Nomor 20 Tahun 2003 bahwa pendidikan adalah usaha sadar dan terencana untuk mewujudkan suasana belajar dan proses pembelajaran agar siswa secara aktif mengembangkan potensi dirinya untuk memiliki kekuatan spiritual keagamaan, pengendalian diri, kepribadian, kecerdasan, akhlak mulia, serta keterampilan yang diperlukan dirinya, masyarakat, bangsa dan negara. Selain itu, pendidikan juga merupakan kunci utama bagi suatu bangsa untuk menyiapkan masa depan dan sanggup bersaing dengan bangsa lain.

Dunia pendidikan dituntut memberikan respons lebih cermat terhadap berbagai perubahan yang sedang berlangsung di masyarakat. Pergeseran nilai yang terjadi di masyarakat terutama penurunan nilai-nilai karakter bangsa menjadi keprihatinan bagi semua kalangan terlebih para praktisi pendidikan. Lickona, (1991, pp. 13-18) mengungkapkan bahwa ada sepuluh tanda-tanda jaman yang harus diwaspadai, karena jika tanda-tanda itu sudah ada, berarti sebuah bangsa sedang menuju jurang kehancuran. Tanda-tanda yang dimaksud adalah: (1) meningkatnya kekerasan di kalangan remaja, (2) membudayanya ketidakjujuran, (3) adanya rasa saling curiga dan kebencian di antara sesama, (4) semakin rendahnya rasa hormat kepada orang tua dan guru, (5) pengaruh peer group yang kuat dalam tindak kekerasan, (6) semakin kaburnya pedoman moral baik dan buruk, (7) penggunaan bahasa dan kata-kata yang buruk, (8) penyalahgunaan seksual dan anak-anak menjadi cepat dewasa, (9) rendahnya rasa tanggung jawab individu dan warga negara, dan (10) meningkatnya perilaku merusak diri, seperti narkoba, alkohol, dan seks bebas.

Jika dicermati, kesepuluh tanda-tanda tersebut mulai terlihat di Indonesia. Hal tersebut menjadi keprihatinan bagi semua kalangan terlebih dunia pendidikan, sebab pendidikan tidak hanya memegang peranan penting dalam membangun kecerdasan namun juga dalam membangun karakter siswa. Oleh karena itu, proses pendidikan terus ditingkatkan dari segi kualitas untuk mencetak sumber daya manusia yang cerdas, terampil, mandiri, dan berakhlak mulia.

Indonesia telah mengalami beberapa perubahan kebijakan dalam dunia pendidikan dalam rangka pencapaian tujuan pendidikan nasional. Salah satu bentuk kebijakan tersebut adalah dicanangkannya pendidikan karakter bangsa melalui proses pendidikan. Pendidikan karakter bukan sekedar inovasi pendidikan, tetapi juga merupakan reformasi pendidikan yang harus dipersiapkan dan dilaksanakan dengan benar serta melibatkan semua pihak yang terkait dengan penyelenggaraan pendidikan. Sebagaimana tertuang dalam Lampiran Permendikbud Nomor 103 Tahun 2014 bahwa pembelajaran merupakan suatu proses pengembangan potensi dan pembangunan karakter setiap siswa sebagai hasil dari sinergi antara pendidikan yang berlangsung di sekolah, keluarga, dan masyarakat. Jadi diperlukan komunikasi dan kesepahaman antara pihak sekolah, keluarga, dan masyarakat dalam memberikan pendidikan kepada siswa agar potensi yang dimilikinya dapat berkembang secara maksimal serta tertanam karakter mulia dalam diri siswa.

Pendidikan karakter merupakan penerapan nilai-nilai karakter yang digali dari khazanah budaya yang selaras dengan karakteristik masyarakat setempat atau yang juga disebut dengan kearifan lokal, bukan yang didapat dari mencontoh nilai-nilai bangsa lain yang belum tentu sesuai dengan karakteristik dan kepribadian bangsa Indonesia. Kemajuan yang dicapai suatu bangsa menunjukkan bahwa pengembangan karakter bangsa tersebut tidak dapat dilepaskan dari aspek budaya yang selaras dengan karakteristik masyarakatnya. Budaya yang digali dari kearifan lokal bukanlah penghambat kemajuan dalam era global, namun justru menjadi filter budaya dalam meraih kejayaan bangsa. Oleh karena itu, menggali nilai-nilai kearifan lokal merupakan upaya strategis dalam pengembangan karakter bangsa.

Karakter bangsa Indonesia adalah karakter yang dimiliki warga negara Indonesia berdasarkan tindakan-tindakan yang dinilai sebagai suatu kebajikan berdasarkan nilai yang berlaku di masyarakat dan bangsa Indonesia (Balitbang, 2010, p.5). Sebagai upaya penanaman nilai-nilai karakter, pemerintah telah menggalakkan program Pendidikan Budaya dan Karakter Bangsa. Pendidikan Budaya dan Karakter Bangsa diarahkan pada upaya mengembangkan nilainilai yang mendasari suatu kebajikan sehingga menjadi suatu kepribadian diri warga negara.

Pelaksanaan pendidikan karakter di sekolah dasar terintegrasi dalam pembelajaran. Proses pembelajaran Pendidikan Budaya dan Karakter Bangsa dilaksanakan melalui proses belajar aktif. Pengembangan nilai harus 
dilakukan secara aktif oleh siswa sebagai subjek yang akan menerima, menjadikan nilai sebagai miliknya dan menjadikan nilai-nilai yang sudah dipelajarinya sebagai dasar dalam setiap tindakan, maka posisi siswa sebagai subjek yang aktif dalam belajar adalah prinsip utama belajar aktif.

Pendidikan di sekolah dasar merupakan bagian dari sistem pendidikan nasional yang berperan penting dalam menghasilkan sumber daya manusia yang berkualitas. Sejak jenjang pendidikan dasar pula jiwa nasionalisme harus ditanamkan dalam diri siswa. Farahmadnian \& Pacukaj (2014, p. 2676) juga mengungkapkan bahwa "Instead of focusing on the development of the people's intellect, education should be used to develop their character, and thus, their sense of nationalism". Selain berfokus pada pengembangan intelektual masyarakat, pendidikan harus digunakan untuk mengembangkan karakter mereka, termasuk rasa nasionalisme mereka. Harapannya, para siswa menjadi manusia yang mencintai negara dan bangsa mereka serta mengedepankan kepentingan bersama di atas kepentingan pribadi dan kelompok. Oleh karena itu, sekolah dasar menjadi salah satu lembaga yang memegang tanggung jawab besar dalam penanaman nilai nasionalisme atau semangat kebangsaan dalam diri siswa.

Realita di lapangan, semangat nasionalisme para siswa semakin menurun yang ditandai dengan banyaknya siswa yang memilihmilih teman dalam bergaul, kurang menghargai pendapat teman, semakin banyaknya siswa yang lebih menyukai lagu-lagu luar negeri dan melupakan lagu-lagu kebangsaan, makin maraknya siswa yang berkomunikasi dengan bahasa gaul, dan tidak menggunakan bahasa Indonesia yang baik dan benar. Hal tersebut terlihat sepele, namun sesungguhnya menjadi permasalahan besar bagi dunia pendidikan. Nudji (2015, p.407) menjelaskan bahwa “... one of the problems faced by Indonesian nation is dim spirit of nationalism in the young generation. This is attributable to foreign cultural effect..." karena makin maraknya fenomena tersebut, maka perlu ditanamkan nilai-nilai dan semangat kebangsaan atau nasionalisme kepada siswa.

Selain karakter nasionalisme, karakter kreatif siswa juga semakin menurun. Sebagian besar para siswa saat ini cenderung meniru atau menjiplak suatu karya daripada menghasilkan karya sendiri yang merupakan hasil kreasi diri mereka sendiri. Kegiatan pembelajaran merupa- kan sarana yang paling tepat untuk mengembangkan kreativitas siswa, seperti yang disampaikan Supardi US (2011, p. 255) bahwa dalam situasi pendidikan, proses pembelajaran merupakan salah satu dari bentuk kegiatan kreatif. Melalui proses pembelajaran, kreativitas siswa dapat dipupuk dan dikembangkan.

Pada dasarnya, setiap orang memiliki potensi kreatif, hanya saja tidak semua orang dapat mengembangkan potensi yang dimiliki tersebut. Oleh karena itu, sedini mungkin siswa difasilitasi untuk dapat mengembangkan kreativitasnya. Salah satu cara untuk mengembangkan kreativitas siswa yaitu melalui kegiatan pembelajaran. Hal tersebut sejalan dengan pendapat Torrance (Wang, 2011, p. 1) bahwa "creative potential exists among all people, and can be improved through learning."

Upaya meningkatan karakter nasionalisme dan kreatif dimulai dengan pembiasaan yang dilakukan di sekolah dengan mengintegrasikannya ke dalam proses pembelajaran. Oleh karena itu, dibutuhkan perangkat pembelajaran yang dapat mengakomodasi penerapan karakter tersebut dalam pembelajaran. Perangkat pembelajaran juga menjadi pedoman bagi guru dalam melaksanakan pembelajaran.

Perangkat pembelajaran menjadi acuan bagi guru dalam memfasilitasi kegiatan belajar siswa. Akan tetapi, yang terjadi di lapangan terlihat bahwa masih ada sekolah yang mengalami permasalahan terkait perangkat pembelajaran tersebut. Salah satu permasalahan yang muncul adalah kurangnya pemahaman guru tentang model pembelajaran yang tepat untuk meningkatkan karakter siswa serta belum mengintegrasikan nilai-nilai kearifan lokal ke dalam pembelajaran. Selain itu, guru juga belum mengembangkan perangkat pembelajaran yang dapat mengakomodasi pengembangan karakter.

Need assessment dilakukan melalui wawancara, observasi, analisis perangkat pembelajaran yang sudah ada, dan kajian literatur. Berdasarkan hasil wawancara dengan guru kelas IV SD Piyungan, diperoleh informasi bahwa guru tidak menyusun perangkat pembelajaran melainkan hanya menyalin perangkat pembelajaran tahun sebelumnya. Guru membutuhkan perangkat pembelajaran yang mendukung penanaman pendidikan karakter. Selain itu, guru juga belum memahami model collaborative learning. Hal tersebut tentu saja mengakibatkan guru tidak mampu membuat perangkat pembelajaran dengan model colla- 
borative learning yang dapat meningkatkan karakter siswa. Diperoleh pula informasi bahwa karakter nasionalisme siswa relatif rendah yang tampak dari adanya siswa cenderung memilihmilih teman dalam kerja kelompok.

Hasil observasi menunjukkan bahwa Rencana Pelaksanaan Pembelajaran (RPP) yang dimiliki guru memang disinyalir hanya menyalin RPP tahun sebelumnya. Hal tersebut terlihat dari adanya kesalahan penulisan tahun pada RPP. Meskipun proses pembelajaran telah dilaksanakan secara berkelompok akan tetapi pengelompokan tersebut kurang efektif karena masih ada siswa yang kurang aktif dan di sisi lain ada siswa yang mendominasi dalam kelompok. Selain itu, pembagian anggota kelompok kurang bervariasi, ada kelompok yang didominasi siswa laki-laki, dan ada yang didominasi siswa perempuan. Karakter nasionalisme siswa dirasa masih rendah, yang terlihat ketika bekerja kelompok ada siswa yang ingin menang sendiri ketika berdiskusi. Karakter kreatif siswa juga kurang menonjol yang terlihat dari karyakarya siswa yang rata-rata belum memanfaatkan benda-benda yang ada di sekitar siswa.

Hasil analisis perangkat pembelajaran yang sudah ada atau yang digunakan guru menunjukkan bahwa guru belum menggunakan model collaborative learning. Kearifan lokal juga belum dimasukkan ke dalam perangkat pembelajaran. Perangkat pembelajaran yang dibuat oleh guru hanya sebatas materi yang ada di buku siswa. Dengan kata lain, belum ada pengembangan materi dengan memanfaatkan kearifan lokal yang ada di daerah Yogyakarta.

Rendahnya karakter nasionalisme dan kreatif di kalangan siswa sekolah dasar khususnya di Kelas IV SD Piyungan harus segera diatasi. Dibutuhkan pembelajaran yang mengintegrasikan kearifan lokal untuk lebih mendekatkan siswa pada daerahnya sekaligus memupuk rasa bangga pada keindahan alam dan budaya yang dimiliki. Model pembelajaran yang cocok untuk menanamkan nilai karakter tersebut adalah collaborative learning. Dengan pengintegrasian kearifan lokal dalam collaborative learning diharapkan pembelajaran menjadi lebih menyenangkan dan bermakna bagi siswa serta dapat meningkatkan karakter nasionalisme dan kreatif siswa.

Prinsip yang mendasari collaborative learning adalah kegiatan saling belajar, dan saling berbagi sehingga dari kegiatan pembelajaran dengan model ini tidak ada siswa yang melejit sendiri, dan tidak ada pula siswa yang tertinggal sendiri. Sato (2012, pp.22-29) menyatakan bahwa collaborative learning adalah metode yang membuat siswa saling belajar. Dalam pembelajaran ada hubungan timbal balik atau hubungan saling mengajari. Collaborative learning merupakan kegiatan belajar melalui kolaborasi antarsiswa. Siswa saling belajar melalui teman sebaya dan berbagi pengetahuan.

Collaborative learning tidak mengedepankan sistem kompetisi antarsiswa. Siswa yang memiliki kemampuan lebih membantu siswa yang kurang mampu, begitu pula sebaliknya, siswa yang merasa kurang mampu tidak malu untuk meminta bantuan pada siswa yang mampu, sehingga tercipta suasana saling belajar yang merupakan ciri khas collaborative learning. Hal tersebut didukung hasil penelitian Ayon, (2013, p. 104) yang mengungkapkan bahwa pembelajaran dengan model collaborative learning mengembangkan keterampilan inter-personal siswa. Keterampilan interpersonal tersebut antara lain berupa keterampilan untuk bekerja sama dalam kelompok, mengenali dan merespons perasaan orang lain, menjadi pendengar yang baik bagi orang lain, dan menyampaikan pendapat secara jelas. Ide collaborative learning berasal dari teori ZPD oleh Vygotsky dengan konsep learning together. Vygotsky menekankan bahwa guru harus menciptakan banyak kesempatan bagi siswa untuk saling belajar dengan teman sebaya dalam mengkonstruk pengetahuan atau membangun konsep secara bersama (Santrock, 2010 , p. 390). Penerapan pendidikan karakter khususnya di sekolah dasar menjadi lebih efektif dengan model collaborative learning.

Dari latar belakang tersebut, dapat disimpulkan bahwa guru membutuhkan perangkat pembelajaran untuk meningkatkan karakter nasionalisme dan kreatif siswa. Hal ini sejalan dengan hasil penelitian dari Qodriyah \& Wangid (2015, p. 177) bahwa perangkat pembelajaran yang dikembangkan dengan baik, efektif dan layak, dapat meningkatkan karakter kejujuran dan kepedulian siswa sekolah dasar. Perangkat pembelajaran yang dimaksud berupa silabus, Rencana Pelaksanaan Pembelajaran (RPP), dan instrumen evaluasi yang merupakan salah satu komponen RPP. Perangkat pembelajaran untuk mengembangkan karakter nasionalisme dan kreatif belum dikembangkan di SD Piyungan sehingga akan sangat bermanfaat dan dapat digunakan sebagai pedoman guru dalam melaksanakan pembelajaran. 


\section{Jurnal Prima Edukasia, 5 (1), January 2017 - 5}

Arifah Nur

\section{Metode}

Penelitian ini menggunakan model penelitian dan pengembangan dari Gall, Gall, \& Borg, (2007). Namun, penelitian ini hanya dilaksanakan sampai pada tahap kesembilan, yaitu: (1) penelitian pendahuluan dan pengumpulan informasi, (2) perencanaan, (3) pengembangan draf produk, (4) uji coba terbatas, (5) merevisi hasil uji coba terbatas, (6) uji coba lapangan, (7) penyempurnaan produk hasil uji coba lapangan, (8) uji coba lapangan operasional, dan (9) penyempurnaan produk akhir.

\section{Desain Uji Coba Produk}

Uji coba produk terdiri atas tiga tahap yaitu uji coba terbatas, uji coba lapangan dan uji coba lapangan operasional. Sebelum uji coba, produk perangkat pembelajaran divalidasi oleh ahli materi dan ahli pembelajaran. Subjek uji coba dalam penelitian ini adalah siswa kelas IV SD Piyungan, Bantul. Subjek sebanyak 3 siswa diambil dari kelas IV A untuk uji coba terbatas, dan 8 siswa untuk uji coba lapangan. Kelas IVB sebagai kelas eksperimen dengan jumlah siswa 30 orang dan kelas IVC sebagai kelas kontrol sebanyak 30 siswa.

\section{Instrumen Pengumpulan Data}

Instrumen pengumpulan data yang digunakan dalam penelitian ini adalah skala penilaian produk, pedoman observasi karakter, skala respons guru dan respons siswa.

\section{Teknik Analisis Data}

Data sebelum pelaksanaan penelitian dalam bentuk hasil wawancara, observasi, studi pustaka, dan analisis perangkat pembelajaran yang digunakan oleh guru sebagai analisis kebutuhan (need analysis) pengembangan perangkat pembelajaran. Data tersebut dianalisis menggunakan teknik analisis data kualitatif berdasarkan pendapat Miles, Huberman, \& Saldaña $(2014$, p. 12) yang meliputi tiga tahap, yaitu, data condensation (kondensasi data), data dis-play (penyajian data), dan conclusion drawing/ verification (penarikan kesimpulan/ verifikasi). Data setelah penelitian berupa data kuantitatif dianalisis untuk mendapatkan perangkat pembelajaran yang layak dan efektif. Kelayakan produk yang dihasilkan dianalisis dengan persentase. Penilaian dikatakan memenuhi kriteria jika kategori minimal yang dicapai adalah baik.

\section{Hasil dan Pembahasan}

\section{Studi Pendahuluan}

Berdasarkan hasil wawancara dengan guru, diperoleh informasi bahwa guru tidak menyusun perangkat pembelajaran, melainkan hanya mengunduh dari internet untuk silabus. Sedangkan untuk RPP, guru hanya menyalin RPP tahun sebelumnya. Guru juga menyampaikan bahwa ia membutuhkan perangkat pembelajaran yang dapat dijadikan pedoman untuk menanamkan nilai-nilai karakter pada siswa. Selain melalui wawancara, informasi juga didapat melalui observasi untuk mengetahui gambaran awal tentang karakter siswa dan proses pembelajaran beserta perangkat pembelajaran yang digunakan. Pada saat proses pembelajaran siswa sudah dikondisikan untuk belajar secara berkelompok. Namun, pembagian kelompok kurang bervariasi. Selain itu, masih adanya kompetisi antarsiswa dalam satu kelompok maupun kompetisi antarkelompok. Adanya kompetisi inilah yang menjadi salah satu penyebab sikap egois siswa, kurang peduli terhadap teman, bahkan menyebabkan rendahnya kreativitas siswa, sehingga pembelajaran secara berkelompok yang telah diterapkan kurang efektif.

Pada tahap studi pustaka, peneliti melakukan kajian terhadap teori tentang perangkat pembelajaran, pembelajaran tematik integratif, model collaborative learning, serta kearifan lokal. Kegiatan yang dilakukan adalah dengan menganalis buku-buku dan jurnal. Kajian buku yang dianalisis adalah mengenai perangkat pembelajaran yang meliputi silabus, RPP, pembelajaran tematik integratif, model collaborative learning, kearifan lokal, dan karakteristik siswa kelas IV SD.

Pada tahap analisis perangkat pembelajaran yang digunakan di kelas IV SD Piyungan, dapat diketahui bahwa perangkat pembelajaran yang digunakan belum sesuai dengan kebutuhan untuk meningkatkan karakter siswa. Perangkat pembelajaran yang telah ada juga belum menggunakan model pembelajaran yang dapat meningkatkan karakter siswa dan belum memasukkan nilai-nilai kearifan lokal daerah setempat.

Dari hasil studi pendahuluan dapat disimpulkan bahwa guru tidak membuat perangkat pembelajaran yang sesuai dan guru membutuhkan perangkat pembelajaran. Oleh karena itu, penelitian ini difokuskan untuk mengembangkan perangkat pembelajaran colla- 


\section{Jurnal Prima Edukasia, 5 (1), January 2017 - 6 \\ Arifah Nur}

borative learning berbasis kearifan lokal untuk meningkatkan karakter nasionalisme dan kreatif siswa kelas IV SD Piyungan, Bantul.

\section{Data Hasil Validasi Ahli}

Data hasil penilaian produk oleh ahli materi diperoleh persentase untuk silabus sebesar 91,10, untuk RPP dan instrumen evaluasi sebesar 92,80. Artinya, perangkat pembelajaran layak digunakan setelah revisi. Ahli pembelajaran memberikan penilaian sebesar 92,60, untuk RPP dan instrumen evaluasi sebesar 93,78 . Ini juga berarti bahwa perangkat pembelajaran layak digunakan setelah revisi.

Analisis Data Hasil Uji Coba Terbatas

\section{Observasi Karakter Siswa}

Penilaian karakter siswa berdasarkan pada karakter yang muncul dari diri siswa selama mengikuti pembelajaran menggunakan perangkat pembelajaran hasil pengembangan. Sebelum mengikuti pembelajaran dengan menggunakan perangkat pembelajaran collaborative learning berbasis kearifan lokal, rata-rata skor karakter nasionalisme siswa sebesar 16,67, sedangkan rata-rata skor karakter kreatif sebesar 16. Setelah mengikuti pembelajaran yang dimaksud, rata-rata skor karakter nasionalisme siswa adalah 20,33 dan rata-rata skor karakter kreatif sebesar 20,67.

\section{Analisis Data Hasil Uji Coba Lapangan}

\section{Observasi Karakter Siswa}

Berikut diagram yang menggambarkan peningkatan karakter nasionalisme siswa pada uji coba lapangan.

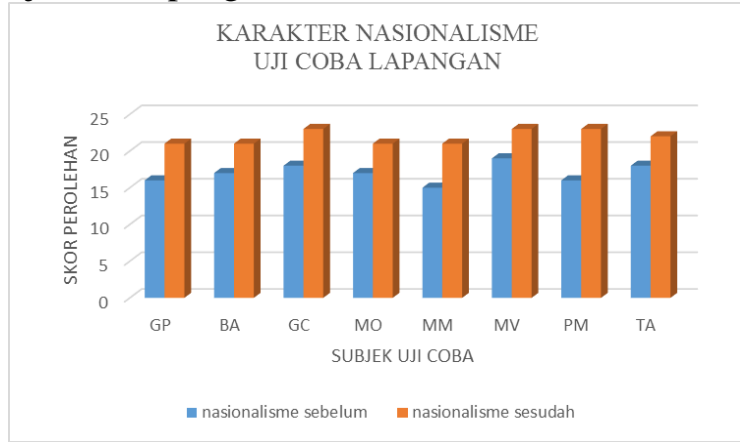

Gambar 1. Grafik Perbandingan Hasil Observasi Karakter Nasionalisme Uji Coba Lapangan

Grafik di atas menunjukkan peningkatan karakter nasionalisme dari 8 siswa sebagai subjek uji coba lapangan. Skor karakter nasionalisme siswa setelah mengikuti pembelajaran lebih tinggi dibandingkan skor karakter nasionalisme sebelum mengikuti pembelajaran. Berikut diagram yang menggambarkan peningkatan karakter kreatif siswa pada uji coba lapangan.

\section{KARAKTER KREATIF UJI COBA LAPANGAN}

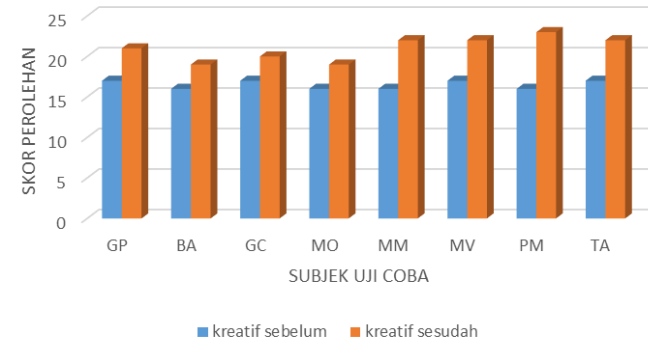

Gambar 2. Grafik Perbandingan Hasil Observasi Karakter Kreatif Uji Coba Lapangan

Grafik di atas menunjukkan peningkatan karakter kreatif siswa pada uji coba lapangan. Skor karakter kreatif siswa setelah mengikuti pembelajaran dengan menggunakan perangkat pembelajaran collaborative learning berbasis kearifan lokal lebih tinggi dibandingkan skor karakter kreatif sebelum mengikuti pembelajaran dengan menggunakan perangkat pembelajaran collaborative learning berbasis kearifan lokal. Analisis Data Hasil Uji Coba Lapangan
Operasional

\section{Observasi Karakter Siswa}

Perolehan skor karakter nasionalisme kelas eksperimen pada uji coba lapangan operasional termasuk dalam kategori sangat baik. Adapun hasil observasi karakter nasionalisme di kelas kontrol berkategori cukup baik. Perolehan nilai karakter kreatif pada uji coba lapangan operasional berkategori sangat baik. Sedangkan hasil observasi karakter kreatif di kelas kontrol berkategori cukup baik.

\section{Respons Guru dan Siswa}

Respons guru setelah menggunakan perangkat pembelajaran collaborative learning berbasis kearifan lokal adalah sangat baik. Sedangkan siswa memberikan respons yang baik pada pembelajaran yang menggunakan perangkat pembelajaran collaborative learning berbasis kearifan lokal.

Pembahasan

Berdasarkan hasil revisi dari ahli, guru, dan temuan pada saat uji coba di lapangan, 
dihasilkan produk akhir. Kajian produk akhir pengembangan perangkat pembelajaran ini merupakan hasil konfirmasi antara kajian teori dan temuan penelitian sebelumnya. Perangkat pembelajaran berupa silabus, RPP, dan instrumen penilaian yang dikembangkan dalam penelitian ini layak untuk digunakan menurut ahli materi dan ahli pembelajaran. Perangkat pembelajaran tersebut mempunyai konsep yang jelas, disajikan dengan petunjuk yang jelas, dan materi yang digunakan sesuai dengan kompetensi inti dan kompetensi dasar.

Perangkat pembelajaran yang berupa silabus disusun sesuai dengan Permendikbud No. 65 Tahun 2013 tentang Standar Proses Pendidikan Dasar da Menengah, yaitu memuat identitas sekolah, kompetensi inti, kompetensi dasar, tema, materi pokok, kegiatan pembelajaran, penilaian, alokasi waktu, dan sumber belajar. Selain itu, silabus yang dikembangkan juga sesuai dengan prinsip-prinsip pengembangan silabus sebagaimana yang ditentukan oleh Arifin (2011, p.193), yaitu prinsip ilmiah, relevan, sistematis, konsisten, memadai, aktual dan kontesktual, fleksibilitas, dan menyeluruh.

Perangkat pembelajaran yang berupa RPP disusun dengan memperhatikan komponen-komponen yang tertuang dalam Permendikbud Nomor 103 Tahun 2014 tentang Pembelajaran pada Pendidikan Dasar dan Pendidikan Menengah, yaitu identitas, memuat KI dan $\mathrm{KD}$, rumusan indikator, materi, media dan sumber belajar, metode pembelajaran, kegiatan pembelajaran, adanya LKS untuk membantu kemandirian belajar siswa, penilaian hasil belajar untuk mengukur ketercapaian belajar siswa, memperhatikan penggunaan bahasa, serta kesesuaian dengan karakter yang akan ditingkatkan.

Perangkat pembelajaran yang dikembangkan dalam penelitian ini menggunakan pendekatan tematik integratif yang memiliki ciri-ciri antara lain: berpusat pada anak, memberikan pengalaman langsung pada anak, pemisahan antarmuatan pelajaran tidak begitu jelas, menyajikan konsep dari berbagai pelajaran dalam satu proses pembelajaran (saling terkait antarmuatan pelajaran yang satu dengan lainnya), bersifat luwes (keterpaduan berbagai muatan pelajaran); hasil pembelajaran dapat berkembang sesuai dengan minat dan kebutuhan anak (melalui penilaian proses dan hasil belajarnya).

RPP yang dikembangkan disusun menggunakan model collaborative learning.
Pembelajaran dirancang untuk mengaktifkan siswa melalui kegiatan diskusi kelompok, tanpa adanya persaingan antar siswa maupun antar kelompok. Pemilihan model collaborative learning juga sesuai dengan karakteristik siswa sekolah dasar, bahwa siswa membutuhkan bimbingan guru atau orang dewasa terutama untuk membimbingnya dalam belajar. Selain itu, adanya kegiatan diskusi dan kerja sama antara dua siswa atau lebih dalam memecahkan masalah secara bersama-sama, adanya tujuan yang ingin dicapai, rasa saling peduli antarteman, serta tidak adanya kompetisi belajar yang ada adalah kegiatan saling belajar, sehingga dapat menciptakan suasana belajar yang nyaman bagi siswa. Jadi penggunaan model collaborative learning dalam pembelajaran sangat cocok dan sesuai dengan karakteristik siswa SD.

Inti dari collaborative learning adalah adanya komunikasi antar siswa, untuk saling berbagi pengetahuan. Siswa yang pandai membantu siswa yang kurang pandai. Dengan rancangan kegiatan pembelajaran tersebut dapat meningkatkan karakter kreatif siswa. RPP juga memasukkan kearifan lokal berupa nilai-nilai budaya Jawa yang masih dipegang teguh oleh masyarakat dan disesuaikan dengan materi pembelajaran berupa tempat-tempat wisata di daerah Yogyakarta, untuk meningkatkan nasionalisme siswa.

Perangkat pembelajaran collaborative learning berbasis kearifan lokal ini mampu meningkatkan karakter nasionalisme dan kreatif siswa. Perangkat pembelajaran tidak hanya dapat digunakan dan bermanfaat bagi guru saja, namun juga memberikan manfaat bagi siswa. Sebagaimana pernyataan Tyagi (2014, p.14), bahwa "... for developing a student active teaching approach that relies on promising syllabus, conceptual quizzes, peer interaction, self-reflection through an after class feedback form. Untuk mengembangkan pendekatan belajar yang mengaktifkan siswa dalam kegiatan belajar adalah tergantung pada silabus, konsep pembelajaran yang jelas, interaksi antarsiswa dan refleksi setelah pembelajaran.

Collaborative Learning didasarkan pada teori Zone of Proximal Development (ZPD) oleh Vygotsky. Vygotsky (1978, p. 86) menyatakan bahwa zone of proximal development merupakan "... the distance between the actual developmental level as determined by independent problem solving and the level of potential development as determined through 
problem solving under adult guidance or in collaboration with more capable peers. Zone of Proximal Development (ZPD) merupakan jarak yang membedakan tingkat perkembangan aktual dengan tingkat perkembangan potensial dalam pemecahan masalah yang dilakukan secara mandiri, dengan pemecahan masalah di bawah bimbingan orang dewasa atau bekerja sama dengan rekan-rekan yang lebih mampu. Melalui bimbingan guru dan teman sebaya serta kerja sama antarsiswa tersebut, karakter kreatif siswa akan muncul dan berkembang.

Model kolaboratif didasarkan pada asumsi-asumsi mengenai proses belajar siswa. Salah satu asumsi belajar yang tersebut adalah belajar merupakan suatu kegiatan aktif dan konstruktif. Ketika siswa mempelajari suatu bahan pelajaran, siswa terlibat secara aktif dengan bahan tersebut. Siswa perlu mengintegrasikan bahan baru tersebut dengan pengetahuan yang telah dimiliki sebelumnya. Siswa membangun makna atau mencipta sesuatu yang baru yang terkait dengan bahan pelajaran. Proses membangun makna atau mencipta sesuatu yang baru tersebut melatih kreativitas siswa.

Prieto et al. (2006, p. 279) melihat kreativitas sebagai konstruk sosial yang merupakan hasil dari interaksi antarindividu. Pembelajaran kolaboratif sangat mengedepankan interaksi dan kerja sama antarindividu sehingga sangat efektif untuk meningkatkan karakter kreatif siswa. Selain itu, pembelajaran yag didesain menggunakan model collaborative learning sangat tepat diterapkan untuk siswa sekolah dasar karena mampu menumbuhkan karakter-karakter positif antara lain tanggung jawab, kerja keras, kerja sama, kreatif, rasa peduli, dan toleransi.

Pembelajaran dengan menggunakan model collaborative learning membuat para siswa merasa nyaman dalam beraktivitas secara berpasangan atau dalam sebuah kelompok belajar, sehingga mereka dapat bekerja secara bersama-sama. Siswa juga nyaman dengan kegiatan yang bisa dilakukannya dengan menggunakan berbagai kemampuan yang ada (seperti melakukan penelitian dan melaporkannya) dibandingkan kegiatan pembelajaran yang berulang-ulang dan membosankan (seperti latihan soal). Dalam kegiatan pembelajaran seperti ini, siswa diberi kebebasan berkreasi menghasilkan produk, mengidentifikasinya bersama, lalu mempresentasikannya di depan kelas. Collaborating learning juga memberi peluang bagi para siswa untuk bertukar pikiran atau ide kepada rekan mereka, sehingga mereka menemukan cara yang berbeda untuk bersosialisasi dan berinteraksi secara akrab dan penuh perhatian.

Mendesain lingkungan belajar dengan model pembelajaran kolaboratif yang mengedepankan kerja sama dan saling berbagi pengetahuan antar siswa sangat cocok untuk memunculkan potensi kreatif siswa, karena siswa yang kurang pandai dan terampil tidak segan untuk bertanya dan meminta bantuan pada temannya yang pandai. Hal tersebut sesuai dengan Hartanto (2011, p.13) yang menyebutkan bahwa kreativitas berasal dari potensi bawaan individu dan pengaruh lingkungan, maka potensi kreatif yang ada pada individu dapat ditumbuhkembangkan dengan cara menciptakan kondisi-kondisi lingkungan.

Selain itu, Habib (2013, p.12) juga menyebutkan bahwa hubungan baik dengan banyak orang dapat membantu seseorang mengembangkan kreativitasnya karena akan banyak mendapat bantuan dan masukan yang bersifat membangun. Model collaborative learning yang mengedepankan kerja sama antaranggota kelompok, sangat membantu penanaman karakter kreatif.

Starko, (2013, p. 269) menyebutkan bahwa "finally, competition can inhibit motivation and quality in creative efforts". Kompetisi individu dan kompetisi antarkelompok dapat meng-hambat motivasi dan upaya kreatif siswa. Oleh karena itu, collaborative learning sangat cocok untuk menanamkan karakter kreatif siswa, sebab dalam model pembelajaran ini tidak ada persaingan atau kompetisi antarsiswa dan antarkelompok. Pembelajaran dengan model collaborative learning lebih mengedepankan kerja sama dan berbagi pengetahuan antarsiswa.

Perangkat pembelajaran yang dikembangkan berbasis kearifan lokal. Setiyadi (2013, p. 294) menjelaskan bahwa "Local wisdom can be various. Local wisdom in a society can be found in the forms of songs, wise words, proverbs, advise, slogans, and ancient books united in the society's daily activities". Kearifan lokal yang dimasukkan dalam perangkat pembelajaran berupa kata-kata bijak, nasihat, dan kebiasaan sehari-hari masyarakat disesuaikan dengan materi pada setiap pertemuan.

Pengintegrasian kearifan lokal dalam pembelajaran merupakan suatu upaya dalam rangka mewujudkan lingkungan pendidikan yang harmoni dan berkelanjutan melalui pe- 
manfaatan pengetahuan lokal dengan pendekatan kontekstual dan partisipatif. Dengan mengenal budaya-budaya lokal yang disampaikan melalui pembelajaran, siswa akan lebih mencintai dan menghargai budaya dan kekayaan alam daerahnya. Di samping itu, melalui pembelajaran berbasis kearifan lokal siswa dilibatkan secara aktif untuk menjaga dan melestarikan kekayaan alam, budaya, dan potensipotensi lokal yang dimiliki daerahnya.

Pengintegrasian kearifan lokal tersebut dapat meningkatkan karakter nasionalisme siswa. Hal tersebut sesuai dengan pendapat Wuryandani (2010, p. 1) bahwa melalui integrasi nilai-nilai kearifan lokal dalam pembelajaran, nilai nasionalisme siswa dapat ditumbuhkan dan ditingkatkan.

Meliono (2016, p. 221) juga menyampaikan bahwa "... local wisdom and multiculturalism are appropriate teaching material for the education of the Indonesian youth as they edify some values such as nationalism, harmony, and moral to build an identity." Kearifan lokal dan multikulturalisme merupakan materi mengajar yang sesuai untuk pendidikan pemuda Indonesia karena meneguhkan beberapa nilai seperti nasionalisme, harmoni, dan moral untuk membangun sebuah identitas. Nilai-nilai kearifan lokal perlu ditegakkan untuk membangun rasa nasionalisme siswa. Adanya kesadaran dan tumbuhnya nilai-nilai kearifan lokal dapat mendorong setiap individu untuk berpikir bijak tentang kepentingan negaranya. Oleh karena itu, dengan menanamkan nilai-nilai kearifan lokal, rasa nasionalisme siswa akan tumbuh dan meningkat.

Hasil uji coba lapangan operasional menunjukkan peningkatan karakter siswa setelah mengikuti pembelajaran dengan menggunakan perangkat collaborative learning berbasis kearifan lokal. Selain itu, hasil penelitian juga menunjukkan adanya perbedaan antara kelas eksperimen yang mendapat perlakuan berupa penggunaan perangkat pembelajaran collaborative learning berbasis kearifan lokal dengan kelas kontrol yang tidak menggunakan perangkat pembelajaran hasil pengembangan tersebut. Perangkat pembelajaran yang berupa silabus, RPP, dan instrumen evaluasi terbukti layak dan efektif untuk meningkatkan karakter nasionalisme dan kreatif siswa.

\section{Simpulan dan Saran}

Perangkat pembelajaran collaborative learning berbasis kearifan lokal yang dikem- bangkan untuk meningkatkan karakter nasionalisme dan kreatif dinilai layak untuk digunakan menurut ahli materi dan ahli pembelajaran dengan nilai sangat valid.

Perangkat pembelajaran collaborative learning berbasis kearifan lokal terbukti efektif untuk meningkatkan karakter nasionalisme dan kreatif siswa kelas IV SD Piyungan. Hal ini berdasarkan hasil uji coba lapangan operasional yang menunjukkan nilai sig $<0.05$, yang berarti ada perbedaan yang signifikan terhadap karakter nasionalisme dan kreatif antara siswa yang mengikuti pembelajaran dengan menggunakan perangkat collaborative learning berbasis kearifan lokal dan siswa yang mengikuti pembelajaran tanpa menggunakan perangkat pembelajaran hasil pengembangan.

Pengembangan perangkat pembelajaran collaborative learning berbasis kearifan lokal untuk meningkatkan karakter nasionalisme dan kreatif siswa kelas IV SD Piyungan sudah diuji kelayakan dan keefektifannya. Oleh karena itu, disarankan kepada guru untuk: (1) menggunakan perangkat pembelajaran ini sebagai pedoman pelaksanaan pembelajaran yang dapat meningkatkan karakter nasionalisme dan kreatif siswa, dan (2) menggunakan produk perangkat pembelajaran ini dengan penyesuaian pada karakteristik siswa dan lingkungan sekitar sekolah.

\section{Daftar Pustaka}

Arifin, Z. (2011). Konsep dan model pengembangan kurikulum. Bandung: PT Remaja Rosdakarya.

Ayon, N. S. (2013). Collaborative learning in English for specific purposes ( ESP ) courses: Effectiveness and students attitudes towards it. International Journal of Business and Economic Development, 1(3), 95-108.

Balitbang. (2010). Bahan pelatihan pengembangan budaya dan karakter bangsa. Jakarta: Kemdiknas.

Farahmadnian, H., \& Pacukaj, S. (2014). Nationalism Based on Western Education in the Characters in "Child of All Nations." Mediterranean Journal of Social Sciences, 5(20), 2676-2681. http://doi.org/10.5901/mjss.2014.v5n20p 2676

Gall, M. D., Gall, J. P., \& Borg, W. R. (2007). An Introduction to Educational Design Research. East, 129. Retrieved from 
www.slo.nl/organisatie/international/publ ications

Habib, M. A. F. (2013). Mahasiswa kreatif perguruan tinggi negeri di Surabaya (studi deskriptif tentang kehidupan mahasiswa kreatif). Web.unair.ac.id/admin/file/f_19997_jurn al.pdf. Diakses 20-12-2015.

Hartanto. (2011). Mengembangkan kreatifitas siswa melalui pembelajaran matematika dengan pendekatan inkuiri. Jurnal Kependidikan Triadik. Vol. 14. No. 1.

Lickona, T. (1991). Educating for character: how our schools can teach respect and responsibility. Nuw York: Bantam.

Meliono, I. (2016). Understanding the Nusantara Thought and Local Wisdom as an Aspect of the Indonesian Education. TAWARIKH, 2(2). Retrieved from http://www.mindamasjournals.com/index.php/tawarikh/article/ view/392

Menteri Pendidikan dan Kebudayaan. (2013). Permendikbud Nomor 65 Tahun 2013 Tentang Standar Proses Pendidikan Dasar dan Menengah.

Menteri Pendidikan dan Kebudayaan. (2013). Permendikbud Nomor 103 Tahun 2014 Tentang Pembelajaran pada Pendidikan Dasar dan Pendidikan Menengah.

Miles, M. B., Huberman, A. M., \& Saldaña, J. (2014). Qualitative data analysis: a methods sourcebook. Los Angeles: Sage.

Nudji. (2015). An effort to enhance sense of nationalism for students of senior high school through Pendidikan Pancasila and Kewarganegaraan (PPKN). Journal of Academic Research International. Vol. 6(1), pp. 405-411.

Prieto, M. D., Parra, J., Ferrándo, M., Ferrándiz, C., Bermejo, M. R., \& Sánchez, C. (2006). creative abilities in early childhood. Journal of Early Childhood Research, 4(3), 277-290. http://doi.org/10.1177/1476718X060675 80

Qodriyah, S. H., \& Wangid, M. N. (2015). Pengembangan SSP tematik integratif untuk membangun karakter kejujuran dan kepedulian siswa SD kelas II. Jurnal Prima Edukasia, 3(2), 177. http://doi.org/10.21831/jpe.v3i2.7222
Republik Indonesia. (2003). Undang-Undang RI nomor 20, Tahun 2003, tentang sistem pendidikan nasional

Santrock, J. (2010). Educational Psychology. Handbook of Educational Psychology. http://doi.org/10.1146/annurev.ps.05.020 154.002041

Setiyadi, D. B. P. (2013). Discourse analysis of Serat Kalatidha: Javanese cognition system and local wisdom. Asian Journal of Social Sciences \& Humanities, 2(4), 292-300.

Starko, A. J. (2013). Creativity in the Classroom: Schools of Curious Delight (5 edition). New York: Routledge. Retrieved from https://www.amazon.com/CreativityClassroom-Schools-CuriousDelight/dp/0415532027

Supardi US. (2011). Peran berpikir kreatif dalam proses pembelajaran matematika. Jurnal Formatif, 2(3), 248-262. Retrieved from http://journal.lppmunindra.ac.id/index.ph p/Formatif/article/viewFile/107/103

Tyagi, P. (2014). Teaching a course with active learning approaches and training other teachers about deep learning stretegies. International Journal for Innovation Education and Research, Vol.2-12, pp. 14-23.

Vygotsky, L. S. (1978). Mind in society: The development of higher psychological processes. Mind in Society The Development of Higher Psychological Processes, Mind in So, 159. http://doi.org/10.1007/978-3-540-927846

Wang, A. Y. (2011). Contexts of creative thinking: a comparison on creative performance of student teachers in Taiwan and the United States. Journal of International and Cross-Cultural Studies, 2(1), 1-14.

Wuryandani, W. (2010). Integrasi nilai-nilai kearifan lokal dalam pembelajaran untuk menanamkan nasionalisme di sekolah dasar. In Proceding seminar nasional lembaga penelitian UNY (pp. 1-10). Yogyakarta: Universitas Negeri Yogyakarta. 